\title{
GIOVANNI SANSONI CORNETTIST, MAESTRO DEI CONCERTI AND COMPOSER IN VENICE, GRAZ AND VIENNA
}

\author{
HERBERT SEIFERT \\ Universität Wien
}

\begin{abstract}
Izvleček: Sansoni je igral na cink, pozavno in fagot, najprej pri sv. Marku v Benetkah nato pa $v$ graški dvorni kapeli in v cesarski kapeli na Dunaju, kjer je bil vodilni inštrumentalist. Napisal je tudi nekaj motetov. V prispevku sta analizirana dva, ki sta bila natisnjena leta 1615.
\end{abstract}

Ključne besede: Giovanni Sansoni, Ferdinand III. (cesar), cink, Gradec, Dunaj.

\begin{abstract}
Sansoni was a player of the cornetto, trombone and bassoon at San Marco in Venice, at the court in Graz and finally at the Imperial chapel in Vienna, where he died as the senior instrumentalist. He composed a few motets. Two of them were printed in 1615 and are the objects of an analysis.
\end{abstract}

Keywords: Giovanni Sansoni, Ferdinand III (Emperor), cornetto, Graz, Vienna.

Two of the motets for two singers in Parnassus Musicus Ferdinandaeus name as their author Giovanni Sansoni. In the first part of this paper I shall give biographical data for this musician, following which I am going to take a look at these compositions.

Sansoni was born around 1593, because at his death, on 15 November 1648, his age is given as 55 years, ${ }^{1}$ which, as experience has shown me, is unlikely to be absolutely precise. The composer Romano Micheli, in his collection of motets by various authors entitled Musica vaga et artificiosa (Venice, 1615), ${ }^{2}$ calls him a "Musicus di Venezia", so he could have been born in the Serenissima. In this context, it is interesting to find a trombone player named Gaspare Sansoni employed at San Marco in Venice in 1593, the possible year of Giovanni's birth; ${ }^{3}$ this could have been his father or some other relative. The earliest documentation we have is the admission of "Zaneto Sanson" to the cappella of San Marco in Venice on 7 December 1614, when he was aged about 21, together with 15 other instrumentalists ${ }^{4}$ engaged by Claudio Monteverdi soon after his appointment as maestro di cappella; another of the new musicians was Giovanni Chilese, who was to

1 Federhofer, "Graz Court Musicians", 202.

2 Micheli, Musica vaga, 41.

3 Selfridge-Field, Venetian Instrumental Music, 298.

4 Fabbri, Monteverdi, 129. 
leave San Marco in $1617^{5}$ and become Sansoni's colleague in Vienna for more than two decades, starting in 1619. Romano Micheli, who styled Sansoni "di Venezia", was himself the maestro di canto at San Marco in July 1614. ${ }^{6}$ His already mentioned collection, Musica vaga et artificiosa, was printed in the same year, and by the same publisher, as the Parnassus Musicus Ferdinandaeus: i. e., in 1615 by Giacomo Vincenti. It contains several pointers to Micheli's connection with the court of Graz - most notably, its dedication to Baron Hanns Jacob Khisl (Khisel) von Kaltenbrunn (1565-1638), at that time a privy councillor of Archduke Ferdinand and steward of the Archduchess. Some of the canons in it were composed by Micheli on soggetti taken from madrigals: one was given to him by Alessandro Orologio, the vice maestro di cappella of Emperor Matthias, and improvised in the presence of both Francesco degl'Atti, a chamber musician of Ferdinand, and the Venetian publisher Bartolomeo Magni. Another madrigal, composed by Luca Marenzio, had been sent to him by Giovanni Priuli, the Archduke's maestro di cappella. Two others, with music by Priuli himself, were given to him by "Sig. Giovanni Sansone, Musico di Venetia", with no mention made of the latter's employment in Graz. And the fourth canon was composed at the request of Degl'Atti on another soggetto by Priuli.

Strangely enough, in a petition for a rise in his salary, written to Archduke Ferdinand early in 1619, Sansoni claimed to have been in the latter's service for about five years, which would place the start of his employment in Graz at least in early 1614: i. e., before his engagement in Venice. Sansoni also stated in this letter to Ferdinand that he had been twice to Italy and had often travelled with his patron during his service. In response, Ferdinand awarded him 800 gulden (florins) as a gratuity. ${ }^{7}$ When Sansoni's application for a knighthood was granted in Regensburg on 5 January 1623, the length of his employment by Ferdinand was stated to be as long as ten years, ${ }^{8}$ which would take its commencement back to early 1613, but one knows of many other instances of the generous rounding-up of years of employment that appear in Viennese documents.

This apparent contradiction would result in the improbable notion that Sansoni was hired first in Graz and then in Venice, while still remaining in the service of the Inner-Austrian court. More convincing would be the temporal sequence of beginning at San Marco and soon afterwards, perhaps early in 1615, relocating to Graz. At all events, Sansoni played wind instruments with cup-shaped mouthpieces such as the cornetto, at that time very much in use, and the trombone, ${ }^{9}$ plus the bassoon, a double-reed woodwind instrument. These facts are confirmed much later by the bassoonist and cornettist Giovanni Antonio Bertoli, five years younger than Sansoni, ${ }^{10}$ who, in the preface to his collection of solo sonatas for bassoon entitled Compositioni musicali (1645), called his older colleague "nel Faggotto \& nel Cornetto eccellentissimo". Bertoli claims that Sansoni, together with his

5 Selfridge-Field, Venetian Instrumental Music, 299.

6 Fabbri, Monteverdi, 296.

7 Federhofer, "Graz Court Musicians", 240-241.

8 Ibid., 241-242.

9 This instrument is given as one of those played by him in Venice in Selfridge-Field, Venetian Instrumental Music, 299.

${ }^{10}$ Bonomo, "Bertoli, Giovanni Antonio", 462-463. 
colleague Antonio Bertali, a violinist, had encouraged him to publish his sonatas. ${ }^{11}$ In documents, however, Sansoni usually styled himself merely "cornetista".

The year 1619 was a good one not only for the Archduke, who acquired the Imperial crown, but also for his court musician Sansoni. In February the musician was awarded an extra payment of 800 guilders by Ferdinand, and on 16 April, before the new Emperor's move with the whole of his court to Vienna, Sansoni married in Graz the oldest chambermaid of the archducal and royal children, Susanne Leobnegg. He invited to the marriage Ferdinand, at that time King of Hungary and Bohemia, who sent in his stead his Kapellmeister, Giovanni Priuli, bearing a present in the form of a goblet worth 30 gulden. ${ }^{12}$ Less than three years later, in January 1623, Sansoni was ennobled by the Emperor - not an altogether unusual honour for court musicians. In the Latin document confirming this title Ferdinand stated that Sansoni had served him for ten years with punctiliousness, modesty, integrity and diligence at home and abroad, on both stringed and wind instruments, and in an excellent manner. ${ }^{13}$ If one can trust these flattering characterizations, Sansoni appears to have occasionally performed on string instruments as well.

We know of four children whom Sansoni had baptized in the church adjoining the Imperial palace, St. Michael, during the early 1620s. ${ }^{14}$ Most noteworthy is the godmother of his daughter Caecilia Elisabeth on 12 November 1625: Princess Maria Margaretha von Eggenberg, daughter of the Imperial Steward and Governor of Inner Austria, Prince Johann Ulrich von Eggenberg, a very influential man.

The Emperor expressed his esteem for Sansoni also by awarding him high-value gratuities over and above his specified salary: In 1628 he was given 8,000 gulden, ${ }^{15}$ in 1637 a further 4,000, and in 1648, shortly before his death, 6,000 more gulden, which were paid to his widow.

Moreover, Sansoni was remembered with legacies in the wills of fellow court musicians. The retired vice maestro di cappella of emperors Rudolf and Matthias, Alessandro Orologio, not only designated him and Pietro Verdina as his sole heirs in his will of February 1633, but in addition left him a house in Udine. ${ }^{16}$

The earliest evidence for Sansoni's activity as a teacher of instrumentalists comes from 1618, when he declared his willingness to teach, in Graz, the young Paul Rauch, Georg Poss's stepson, ${ }^{17}$ who from 1619 would likewise serve in Vienna up to his death in 1641. When Rauch married there in 1633, Sansoni was his best man, ${ }^{18}$ in which function he served on the occasion of several other marriages of his colleagues, almost all of them instrumentalists such as Pietro Verdina; ${ }^{19}$ the sole singer among them was, in 1642 ,

${ }^{11}$ Sartori, Bibliografia, 394.

${ }^{12}$ Federhofer, Graz Court Musicians, 241.

${ }^{13}$ Ibid., 141-142.

${ }^{14}$ Vienna, Pfarre St. Michael, Taufbuch.

${ }^{15}$ Saunders, "Sacred Music", 873.

16 Vienna, Stadt- und Landesarchiv.

${ }^{17}$ Federhofer, Graz Court Musicians, 202.

${ }^{18}$ Vienna, Pfarre Schotten.

${ }_{19}$ Vienna, Pfarre St. Stephan. Verdina married in 1634, when he was maestro di cappella of Archduke Ferdinand (as Emperor, Ferdinand III); from 1637 until his death in 1643 he held the 
the tenor and prolific composer Giovanni Felice Sances..$^{20}$ When the court organist Carlo Ferdinando Simonelli married in 1643, Sansoni was even sent by the Emperor as his deputy to act as best man, together with his Kapellmeister Giovanni Valentini. ${ }^{21}$

But Sansoni was not only a much sought-after best man - I know of ten marriages but also a renowned teacher. Heinrich Schütz recommended in 1627 and again one year later, that the Saxon Elector, Johann Georg I, should send Johann Vierdanck from Dresden to Vienna to study with Sansoni, but the Elector thought this would be too expensive and refused to do so. ${ }^{22}$ Schütz made a similar recommendation around the same time for a choirboy, Gabriel Günther, whose voice had broken, ${ }^{23}$ but we lack evidence that the latter actually went to Vienna. But between about 1638 and $1640^{24}$ Friedrich Werner (1621-1667) was sent by Kurprinz Johann Georg II to study with Sansoni in Vienna, where he was still resident in 1647, at least seven years later. ${ }^{25}$ Werner would later, in 1663, become a senior-ranking instrumentalist in Dresden. ${ }^{26}$ In March 1648 the Kurprinz wrote Sansoni a letter of gratitude for this tuition and sent him a gift. ${ }^{27}$ Here, the cornettist is addressed as "maestro de' concerti nella musica della Sacra Cesarea Maestà", an official title confirmed by a petition that Sansoni himself had written to the Emperor in $1639,{ }^{28}$ and again after his death, when, in 1654, his successor Burghard Kugler petitioned for his own ennoblement and the Emperor stated in response that he had decided to entrust to Kugler Sansoni's post of concertmaster after the latter's death. ${ }^{29}$

From the beginning of 1637 at the latest up to his death, Giovanni Sansoni accommodated in his household about four to six Kapellknaben, boy singers in the chapel. He was paid not only for their board and lodging but also for their tuition and their instruments. ${ }^{30}$ One or two years later he made a request for permission to choose on a regular basis three or four boys as "extraordinary" Kapellknaben in order to teach them music and thereby provide a reservoir for the court chapel. This dispensation was granted to him. ${ }^{31}$ When some of these boys later were admitted to the court chapel, almost all of them served as instrumentalists rather than singers. Two of these pupils of Sansoni were the already mentioned organist Simonelli - to whose marriage he was later delegated as his

post of Ferdinand's vice maestro di cappella. Earlier, between 1616 and 1620, Verdina had played the cornetto at the cathedral of Verona.

${ }^{20}$ Vienna, Pfarre St. Michael, Trauungsbuch, 245. From 1649 to 1669 Sances served as Imperial vice maestro, and from 1669 to 1679 as maestro di cappella.

${ }^{21}$ Vienna, Pfarre St. Michael, Trauungsbuch, 238.

${ }^{22}$ Köhler, "Der Stralsunder Komponist Johann Vierdanck", 404.

${ }^{23}$ Johnston, Heinrich Schütz Reader, 46-47.

${ }^{24}$ This early date is given in Federhofer, Graz Court Musicians, 202.

${ }^{25}$ Johnston, Heinrich Schütz Reader, 151.

${ }^{26}$ Fürstenau, Zur Geschichte der Musik, 25.

27 Johnston, Heinrich Schütz Reader, 161-162.

${ }^{28}$ La Mara, "Briefe", 14.

${ }^{29}$ Vienna, Haus-, Hof- und Staatsarchiv, Familienakten B.

${ }^{30}$ Vienna, Hofkammerarchiv, Hofzahlamtsbücher; Vienna, Haus-, Hof- und Staatsarchiv, Obersthofmeisteramt.

${ }^{31}$ Knaus, Die Musiker, 38. 
representative by the Emperor - and his own successor, the cornettist Kugler. ${ }^{32}$ In February 1645 Sansoni wrote to the Emperor that the four poor "putti di capella" (Kapellknaben) undergoing the rigours of a horrible winter should immediately receive new clothes; this autograph petition serves posterity as a specimen of his handwriting. Ferdinand III commanded that the money be paid: "Lasts also außfertig[en] F[erdinand]" (see the Figure at the end of this article). ${ }^{33}$

In good time before the Christmas of 1644 Sansoni received a handsome quantity of wine from Western Hungary, today the Burgenland in Austria: more precisely, from Németkeresztúr (Ger. Deutschkreutz), where Count Ferenc III Nádasdy had his residence. On 7 December of that year this nobleman sent Sansoni as a gift 6.5 "Eymer" (i. e. buckets) of wine,${ }^{34}$ equivalent to at least about 354 litres - a volume that the musician could have consumed with his household possibly in a year, or could partly have sold. Red wines from this region are still today highly rated. One of Sansoni's pupils, the Kapellknabe Johann Baptist Herbst, had been engaged in July 1643 as a player of the violone in the Imperial court chapel, but early in 1647 Herbst entered the small musical establishment of this Hungarian count in Németkeresztúr for a period of less than two years; ${ }^{35}$ he subsequently returned to Imperial service, in which he remained until his death in 1669.

This information on Sansoni's biography may suffice; many more, not so informative items could be extracted from the archives. The important facts are that he was the senior instrumentalist at the Imperial court, its concertmaster and a highly esteemed teacher. When we consider him as a composer, it should not go unmentioned that the late Gunther Morche from Heidelberg University states in his article on Sansoni published in Die Musik in Geschichte und Gegenwart in 2005 that in his motets preserved in Kremsmünster, to be identified later, Sansoni barely stands back behind his model, the chapel master Giovanni Valentini, ${ }^{36}$ who was certainly a prolific composer whose output was very well known to Morche.

But in 1615, when the Parnassus was published, Valentini could not have been Sansoni's model, since they were both new members of the Graz chapel. According to Morche, Sansoni's motets published there brought the current state of musical development in Venice to a repertory of Milanese provenance, similarly to Alessandro Grandi, who was about the same age but came to Venice from Ferrara only some time after Sansoni, who probably originated from the Serenissima and had been educated in its local style. And certainly, Sansoni was one of the youngest composers represented in the collection.

Both of Sansoni's motets in Parnassus are set for two equal voices and figured basso continuo. For Ego dormio et cor meum vigilat ${ }^{37}$ he chose two altos. This well-known text, which was set to music several times in the early seventeenth century (e. g., by Monteverdi

${ }^{32}$ Vienna, Haus-, Hof- und Staatsarchiv, Obersthofmeisteramt.

${ }^{33}$ Vienna, Hofkammerarchiv, Autographen.

${ }^{34}$ Budapest, Magyar Nemzeti Levéltár, Országos levéltár, A Magyar Kamara archívuma, E 185, Archivum familiae Nádasdy, 30 t., Számadások és vegyes anyag, quoted in Király, "Nádasdy (III.) Ferenc", 981.

35 Ibid.

${ }^{36}$ Morche, "Sansoni, Giovanni".

${ }^{37}$ Antonicek, Parnassus musicus Ferdinandaeus, 101-104. 
and Schütz) is taken from the Canticum canticorum: verse 2 and the beginnings of verses 3 and 5 of chapter 5 were selected for setting by Sansoni:

2 Ego dormio et cor meum vigilat vox dilecti mei pulsantis aperi mihi soror mea amica mea columba mea inmaculata mea quia caput meum plenum est rore et cincinni mei guttis noctium I sleep, and my heart watcheth: the voice of my beloved knocking: Open to me, my sister, mylove, my dove, my undefiled: for my head is full of dew, and my locks of the drops of the nights. expoliavi me tunica mea quomodo induar illa lavi pedes meos quomodo inquinabo illos I have put off my garment, how shall I put it on? I have washed my feet, how shall I defile them? dilectus meus misit manum suam per foramen et venter meus intremuit ad tactum eius My beloved put his hand through the key hole, and my bowels were moved at his touch.

5 surrexi ut aperirem dilecto meo manus meae stillaverunt murra digiti mei pleni murra probatissima I arose up to open to my beloved: my hands dropped with myrrh, and my fingers were full of the choicest myrrh.

Not unexpectedly, our composer provides musical illustration of the antithetical character of the first sentence: "Ego dormio" is recited in long note-values on a monotone, while "et cor meum vigilat" receives short notes and a melisma. From the entry of the second, imitating voice onwards the two figures are combined. Before the repetition of these three bars the continuo alone takes up the first figure, providing one of several instances of its participation in the motivic interplay of the voices. In bars 10 to 17 the second figure is treated separately in imitation in a rising sequence.

The next section is once again opened by the second alto, but there is no imitation. In a dramatic manner the first alto presents his solo in the role of a lover who asks his beloved to let him in, calling her his sister, dove, friend and undefiled person. In the first three of these four invocations Sansoni mirrors the parallelism of the text: "soror mea, amica mea, columba mea" employ the same motive. The repetition of this section of text begins in parallel thirds; the invocations now alternate, only the last one being set in thirds again for climactic effect.

The avoidance of polyphony is maintained in the next section, featuring an alternating repetition of the first part of the text; only the end of verse 2 is set in imitative style, once again as a means of achieving a climax. The rhetorical question of the next verse is likewise sung by the first alto as a solo; it ending with a rising repetition of the interrogative "quomodo" and a rhetorically correct ending of this question with a rising interval.

The first sentence of the fifth verse returns to the narration: The woman has finally risen to open the door. Sansoni switches to triple time; the second alto begins in solo fashion with an upward leap of a fourth, repeating the word "surrexi" a fourth higher. The other voice starts to imitate only after eight bars. The triple-time section ends with singing in thirds; a brief return to common time takes up again the motives for "ut aperirem" and "dilecto meo", with an adapted rhythm and in continuous imitation.

The second motet is a composition for two bass voices setting psalm 132/133, Ecce quam bonum et quam iucundum: ${ }^{38}$

${ }^{38}$ Ibid., 107-110. 
Ecce quam bonum et quam iucundum habitare fratres in unum:

Behold, how good and how pleasing it is for brothers to dwell in unity.

Sicut unguentum in capite, quod descendit in barbam, barbam Aaron, Quod descendit in oram vestimenti eius:

It is like the ointment on the head that descended to the beard, the beard of Aaron, which descended to the hem of his garment.

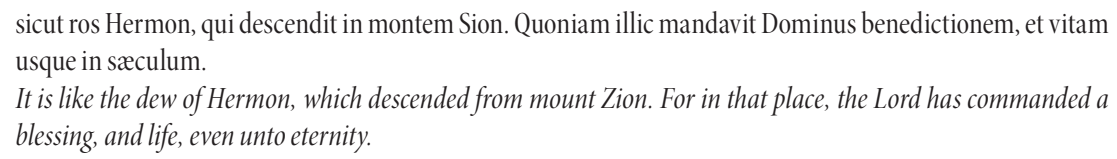

The overall structure is similar to that of Ego dormio, with long solos, imitative passages, homophonic parallel motion, a triple-time section and a return to common time for the ending, which reintroduces motives first heard in the triple-time section. I wish to highlight just a few special features.

One is a short introduction by the continuo alone; the word "unum" ends both times on a unison, similarly to the "unum sunt" in Monteverdi's Duo Seraphim. The melodic descents for "descendit" are quite extensive, and the mountain of "montem Sion" is formed by wide upward and downward leaps. Here, the second bass voice on two occasions lies an octave beneath the continuo, which is not always a basso seguente but often constitutes the lowest note of a triad or has an independent line.

The only other known compositions by Giovanni Sansoni are two motets written for Anton Wolfradt, the Abbot of the monastery of Kremsmünster and the Prince-Bishop of Vienna, in a collection of scores copied between 1633 and 1639 by Father Benedict Lechler and preserved in the library of that monastery. ${ }^{39}$ Laetentur caeli is a polychoral work for two equal choirs and organ for the occasion of the feast of St. Anthony (i. e., for the Abbot's name-day), whereas Beatus Antonius is a modern, few-voiced composition for two sopranos, two tenors, two violins and organ celebrating Wolfradt's birthday.

In conclusion: we have become acquainted with Giovanni Sansoni as a highly esteemed instrumentalist in the Imperial chapels of the two Ferdinands, a teacher of far-reaching renown and the composer of a very small number of motets that have come down to us, but which seem to demonstrate considerable merit. 
De musica disserenda XIII/1-2 • 2017

Sacta cesia haceta

fo' supplicato qia' alcym 'mesi ger $h^{\prime}$ westiti de putti hi capeth che non possotw esser giu' nectessitosi diguello che sotwo, hauxude passato quelt horsido incestho tutfi ftracciati it che riesee di cattica conseguenza al grouederte ds alen uedendo questi cosi mal trattafi; et sin'hora non fo potuto ottenore la vissolu: Fione che ith Linte ho' fatta sollecitare, et won si é nitruata 'a suyplica; per tahto riccorro di nuovo a la clementa sua sugghticande che nogh dar subito ordine the inceliate it payator dicorte coman li gai a suoi minisen che quefti soueri ycattro putti siento quanto prina uestiti - con che fumilis. one le inchino.

tella rac: ces:o hta Nosfra



Figure

The autograph petition of Giovanni Sansoni to Emperor Ferdinand III, February 1645 (Vienna, Hofkammerarchiv, Autographen, Sansoni [reproduced with kind permission])

154 


\section{Sources and Bibliography}

\section{Archival Sources}

Vienna, Haus-, Hof- und Staatsarchiv, Familienakten B.

Vienna, Haus-, Hof- und Staatsarchiv, Obersthofmeisteramt, Sonderreihe 186 and 187.

Vienna, Hofkammerarchiv, Hofzahlamtsbücher 84-95 (1637-1649).

Vienna, Hofkammerarchiv, Autographen, Sansoni.

Vienna, Pfarre Schotten, Trauungsbuch 4, 31v.

Vienna, Pfarre St. Michael, Taufbuch 1608-1642, 214 (22 July 1621), 236 (22 April 1623) and 268 (12 November 1625).

Vienna, Pfarre St. Michael, Trauungsbuch B.

Vienna, Pfarre St. Stephan, Trauungsbuch 14, 489.

Vienna, Stadt- und Landesarchiv, Alte Ziviljustiz: Testament 4870/17. Jh.

\section{LITERATURE}

Antonicek, Theophil, ed. Parnassus musicus Ferdinandeus herausgegeben von Giovanni Battista Bonometti (1615). Denkmäler der Tonkunst in Österreich, 159. Graz: Akademische Druck- u. Verlagsanstalt, 2015.

Bonomo, Gabriele. "Bertoli, Giovanni Antonio". In The New Grove Dictionary of Music and Musicians, 2nd ed., edited by Stanley Sadie, 3:462-463. London: Macmillan, 2001.

Fabbri, Paolo. Monteverdi. Cambridge: Cambridge University Press, 1994. https://dx.doi. org/10.1017/CBO9780511627279.

Federhofer, Hellmut. "Graz Court Musicians and their Contributions to the Parnassus Musicus Ferdinandaeus (1615)”. Musica Disciplina 9 (1955): 189-244.

Fürstenau, Moritz. Zur Geschiche der Musik und des Theaters am Hofe zu Dresden. Dresden: Kuntze, 1861.

Johnston, Gregory S. A Heinrich Schütz Reader: Letters and Documents in Translation. Oxford: Oxford University Press, 2013.

Király, Peter. "Nádasdy (III.) Ferenc rezidenciális zenéje" [Musik in the Residence of Ferenc Nádasdy III]. Századok 144 (2010): 4.

Kellner, Altmann. Musikgeschichte des Stiftes Kremsmünster. Kassel: Bärenreiter, 1956. Knaus, Herwig. Die Musiker im Archivbestand des kaiserlichen Obersthofmeisteramtes (1637-1705). Vol 1. Österreichische Akademie der Wissenschaften, Veröffentlichungen der Kommission für Musikforschung, 7. Vienna: Hermann Böhlau’s Nachf., 1967.

Köhler, Burghardt . "Der Stralsunder Komponist Johann Vierdanck: Herkunft und Aufenthalt in der Sächsischen Hofkapelle". Die Musikforschung 63, no. 4 (2010): 401-406.

La Mara. "Briefe alter Wiener Hofmusiker". Musikbuch aus Österreich 6 (1909), 333.

Morche, Gunther. "Sansoni, Giovanni “. In Die Musik in Geschichte und Gegenwart, 2nd ed., edited by Ludwig Finscher, Personenteil, 14:934-935. Kassel: Bärenreiter; Stuttgart: Metzler, 2005.

Saunders, Steven. "Sacred Music at the Hapsburg Court of Ferdinand II (1615-1637): The Latin Vocal Works of Giovanni Priuli and Giovanni Valentini”. PhD diss., University of Pittsburgh, 1990. 
Sartori, Claudio. Bibliografia della musica strumentale italiana stampata in Italia fino al 1700. Florence: L. Olschki, 1952.

Selfridge-Field, Eleanor. Venetian Instrumental Music from Gabrieli to Vivaldi. New York: Praeger, 1975.

\author{
GIOVANNI SANSONI \\ KORNETIST, MAESTRO DEI CONCERTI IN SKLADATELJ \\ V BENETKAH, GRADCU IN NA DUNAJU
}

Povzetek

Giovanni Sansoni, ki se je rodil okoli leta 1593 v Benetkah, je bil kornetist, pozavnist in fagotist. Leta 1614 ga je za kapelo sv. Marka v Benetkah najel Claudio Monteverdi, od okoli 1615 je bil član nadvojvodske kapele v Gradcu, od leta 1619 dalje pa je deloval v cesarski dvorni kapeli na Dunaju, kjer je bil vsaj od leta 1639 pa do svoje smrti leta 1648 vodilni inštrumentalist (koncertni mojster). Leta 1623 je bil povzdignjen v plemiški stan in je od cesarjev Ferdinanda II. in Ferdinanda III. poleg plače prejemal tudi dodatna darila in volila od svojih kolegov glasbenikov. Najpozneje od leta 1637 pa do smrti je bil zadolžen za vzgojo deških pevcev dvorne kapele. Njegova učiteljska slava se je širila. Heinrich Schütz ga je na primer priporočal saškemu elektorju. Od okoli 1638/40 je elektorski princ Johann Georg II. v uk k Sansoniju poslal Friedricha Wernerja (1621-1667), ki je po sedmih letih 1647 še vedno prebival na Dunaju. Leta 1663 bi moral postati zaslužni inštrumentalist v Dresdnu. Sansoni pa je imel zveze tudi na dvoru madžarskega grofa Ferenca Nádasdyja v Németkeresztúru (nem. Deutschkreutz), danes v Avstriji.

Sansoni je bil tudi skladatelj manjšega števila ohranjenih in sorazmerno kvalitetnih motetov. Dva od teh, ki ju analizira pričujoči prispevek, sta bila objavljena leta $1615 \mathrm{v}$ antologiji Parnassus musicus Ferdinandaeus in Sansoni je bil eden od najmlajših skladateljev, ki so zanjo prispevali svoja dela. Oba moteta sta dvoglasna za par enakih glasov (dva altovska oz. dva basovska) in basso continuo. Njuna zgradba je podobna, z dolgimi solističnimi odseki, malo polifono imitativno ali homofono vzporedno vodenima glasovoma, $\mathrm{s}$ kontrastnim večkrat ponovljenim delom $\mathrm{v}$ tridobni meri in zaključnim povratkom $\mathrm{v}$ dvodobnost. Na več mestih je v polifono igro pevskih glasov vključena tudi basovska inštrumentalna melodija.

Edini drugi znani Sansonijevi skladbi sta moteta za Antona Wolfradta, opata benediktinskega samostana v Kremsmünstru in dunajskega knezoškofa. Ohranila sta se v zbirki, ki jo je sestavil med 1633 in 1639 p. Benedikt Lechler in je še danes ohranjena $v$ knjižnici tega samostana. 